Marcin Stawiarski

Université de Caen Basse-Normandie, ERIBIA (E.A. 2610)

https://doi.org/10.18778/8220-191-8.13

\title{
Vocal Intersemioticity in James Chapman's How Is This Going to Continue?
}

The aim of this article is to consider what Roman Jakobson once described as "intersemiotic translation" - a form of transmutation of signs from one sign system to another (Jakobson 1959: 261) - through its application to the concept of voice in fiction. In this paper, such transmutation assumes the form of a system of intersemiotic transfers which weave together two works belonging to two distinct media: Bernd Alois Zimmermann's composition Requiem für einen jungen Dichter (1969) and James Chapman's novel How Is This Going to Continue? (2007). Chapman's novel draws on Zimmermann's requiem, which is itself founded on a sophisticated network of musical and literary sources. My analysis relies to a great extent on the concepts of intertextuality and intermediality. Since Chapman's novel makes ample use of quotes from vocal performances, I wish to demonstrate that intersemioticity here is closely linked to the treatment of the voice as an intermedial and intertextual collage of fragments and scraps of vocal performances and literary works. Therefore, allusions to performances represent traces of voices, thus an intersemiotic sign of vocal absence. The fragmentary nature of such intersemiotic translation is inscribed within the fundamental aspect of the novel - the text is at once a funeral tribute and a meditation on death. In other words, within the context of the intersemiotic transmutation, Zimmermann's requiem for a poet becomes a tribute to the late singer Kathleen Ferrier and an intermedial inquiry into the nature of death.

The first part of this article focuses on the specificity of the intermedial context for Chapman's text. The second part goes on to investigate the notion of voice by concentrating on its specific intertextuality, which leads to a clash of discourses and exposes a multiple intersemiotic and intertextual construct. 


\section{The Voice of the Dead and the Living: The Intermedial Nature of the Text}

The intersemiotic character of Chapman's novel is immediately obvious. The book presents the reader with a musical system of signs from the very start, owing to its cover showing a musical score, but it also engages with the visual. By being shaped as an A-4 book in horizontal layout, in-plano, with a spiral-binding, instead of being stitched or sewn, it incites us to look at it as a crafted object, like an artisan's hand-made artifact, an amateur's notebook, and a multimedia booklet. With its yellowish cover, it aspires to stand for a unique, precious and quasiarcheological find. Moreover, the novel is supposed to have come out in a limited, signed edition, mine being $26^{\text {th }}$ out of 50 . Hence, the notion of curiosity lies at the heart of the novel.

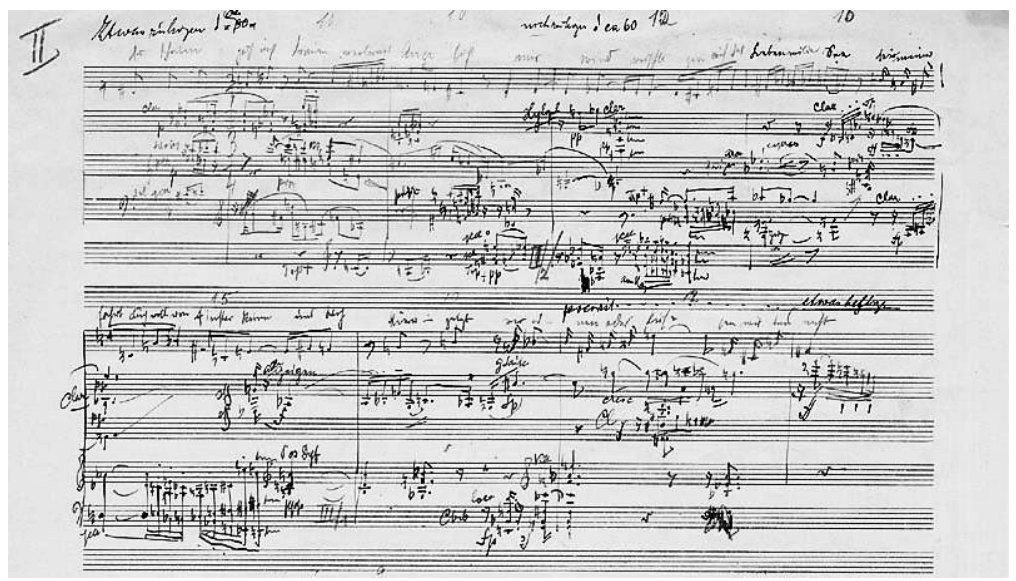

Figure 1. Cover of Chapman's How Is This Going to Continue?

The idiosyncratic nature of the text derives from its generic - intersemiotic - specificity as well. The genre of the work is stated at the title-page, which suggests we are reading "[t]he memoir of Eckhard Unruh's final year as a musician, composed by him for narrators, prerecorded tapes, contralto and baritone soloists, two choirs, chamber orchestra, percussion orchestra, electronic and concrete sounds, electric ukulele, and pipe organ" (Chapman 2007: 3). However, in the back-cover blurb one finds a reference which makes it clear that the text is a novel. Therefore, a multiplicity of genres as well as an interplay of intermedial hybrids are clearly at stake here. 
Furthermore, the intersemiotic hybridity is closely linked to the text's displaying a multi-layered narrative structure. Chapman's novel can be divided into four parts: (a) the first part outlines the book's project - it is a simple one-page introductory notice, stating that what follows is a compact edition of an oratorio - its libretto; (b) the second part is a slightly longer text, i.e. a fictional quote from The New Grove Dictionary of Music and Musicians, presenting the composer's biography, and giving some details as to the circumstances under which the work was composed; (c) the third part, the text proper, which spans over fifty pages, is divided into two sections, or two movements ("First the Wife", "Then the Husband"); (d) finally, the ultimate pages of the text provide the sources and the references of which the text is made.

In stark contrast to its structure, the novel's story is extremely simple. A fictitious, eccentric composer, Unruh Eckhard Rabindranath, who has spent his life composing "exuberant" and "undesirable" works of art (Chapman 2007: 10), characterized as much by minimalism as by gigantism or plagiarism, decides to compose an oratorio following his wife's demise. While his spouse died of breast cancer, Unruh himself suffers from a series of strokes. The text proper of the novel is this oratorio, which constitutes at once a requiem and a tribute to the deceased wife.

Indeed, Chapman's text is founded on the exploration of the theme of death, especially suicide, and the way in which it is articulated with the living. This motif is brought to prominence from the very beginning: the score-like cover of the novel has, in fact, two other layers of glassinelike semitransparent sheets. One gives the title in red characters, How Is This Going to Continue?; the other provides readers with a quote from Montaigne: "But thou diest not because thou art sicke: thou diest because thou art living. Death is able to kill thee without the helpe of any sicknesse" (Chapman 2007: 1). The cover thus announces the novel's main theme as a playful aporia within the articulation of life and death through the ironic echo between Montaigne's citation and the title, as if one notion literally erased the other. It is also already suggestive of multiple aesthetics, making the act of reading not merely the sheer turning of the pages or simple linear deciphering, but the gesture of peeling back layers and disentangling multiple intertextual and intersemiotic threads. The page that has been turned over does not simply disappear from view, but remains in one's hands and is grafted to all the other references that come into play. Like this cover, with its multiple palimpsest-like semi-transparency, the text is predicated on multifarious intermedial references.

While the text engages in a meditation on death, emphasis is placed on the condition of the human body, which is bound to disappear, which 
raises the question of the physical concreteness of the voice. The body is shown to vanish through illness. Many of the fragments are steeped in stark depictions of the dying body: "one iron rod swished through the air and smashed into the skull, cracking it to bits. The legs twitched, one small hand abruptly clutched the air as if she were still alive" (Chapman 2007: 34). The text unrestrainedly exposes decay and physical harm of that "flesh [was] too filthy for the dogs to eat" (Chapman 2007: 27).

By doing so, the novel highlights the question of the individual's trying to come to terms with pain or the loss of bodily faculties. This is clearly the case in the excerpt from an interview with the Czech composer, Bedřich Smetana, who suffered from deafness and mental disorders, and, in considering pain as a bodily function which issues a warning, raises this question: "Did my poor tiny wife really need to be warned for seven months?" (Chapman 2007: 42). Pain is also pondered in a philosophical meditation which refutes the idea of pain as evil and deems it to be "what is necessary to the production of happiness" (Chapman 2007: 35). Finally, André Malraux's Lazarus, written during the writer's stay in hospital, undergoing treatment for neural sickness, lies at the center of the questions of suffering and death, so that the intersemiotic voice also partakes of those ultimate stages of utterance delivered by an agonizing body which is about to yield to the inexpressible.

The vision of the dying body is on a par with the issue of time. Chapman's text depicts transitions, exposing death at the very moment when it overwhelms the individual. Death is considered at the point of its occurrence, as it is just about to happen. It is death in the middle of its advent, the unthinkable moment of ultimate transition. The voice is the voice of the dying or the condemned to die, like in Josef Suk's or Frederick Delius' "deathbed interview [s]" (Chapman 2007: 29) or Archimedes' words reported just "as soldiers were killing him" (Chapman 2007: 39). There is, then, a kairos to death as is evidenced by a fictional quote from Tolstoy: "She was going to experience dying. She did not want to miss it" (Chapman 2007: 34). And this kairos is precisely what is unthinkable - the aporetic moment of transition, within which the body loses its grip on the world, and which is underlined by the quote from Delius: "This same mouth that makes these words now, is going to be dead in a matter of days" (Chapman 2007: 46).

Two forms of illness are placed at the forefront: cancer and stroke/ heart failure. Chapman's text pits the feminine against the masculine not only by the bipartite division of the novel, but also within the very question of illness, since the feminine is mostly associated with cancer - especially through the figure of the female singer Kathleen Ferrier, while 
the masculine translates into strokes or heart failures, attuned to the figure of the composer, the musician or the conductor. Ray Roberts comments on the Canadian pianist's Glenn Gould's stroke, and his death in 1982; Alexander Ivashkin speaks of the Soviet composer, Alfred Schnittke, who suffered several strokes before dying in 1998; Humphrey Burton focuses on the American conductor Leonard Bernstein, who died of a heart attack in 1990; the German philosopher Herbert Marcuse, who died of a stroke himself in 1979, is quoted in the text; so is the American musician John Hurt, who suffered a heart attack and passed away in 1966. Edward Elgar is quoted as saying "[T] he problem is, my wife predeceased me" (Chapman 2007: 39). The prefix "pre-", here, undermines the pure subjectivity of the act of dying and intimates a meditation on death by means of the Self's relationship with the Other, so that the book explores death within the dynamics of relationships.

Indeed, myriads of artist-characters within the novel may be arranged into groups, picturing the specific relationships between the dead and the living: Kathleen Ferrier and her interaction with Winifred Ferrier, John Barbirolli or Maurice Leonard; Virginia and Leonard Woolf; Gustav and Alma Mahler; Bedřich Smetana and his wife Bettina; Alfred Schnittke and his wife Irina. Thus, the notion of death arises out of the confrontation with the dying Other, creating meaning through externality and reciprocal mirroring. Josef Suk's fictional quotation deals with the death of the composer's wife - and Dvorák's daughter, Otilie - at the very moment when he is dying himself: "While my wife, dying, listened to Bach, I heard her seconds being destroyed" (Chapman 2007: 29). It would seem that the trace of the Other's death guides the subject through dying, recalling the mythical Charon, as though there was no conceiving of death beyond the present-absent relationship between the Self and the Other, and as though there was a need to get a grasp of death through otherness.

This is precisely the rationale behind the question of memory as trace. It comes to light either as loss of memory, as in Ivashkin's commentary on Schnittke who, following his illness, had forgotten his Cello Concerto $\mathrm{n}^{\circ} 1$, or through the question of forgetfulness as a self-erasing trace of the Self within the Other. In an obituary of Gustav Mahler, one reads: "We cannot see how any of his music can long survive him" (Chapman 2007: 44). This is the trace of the voice that chimes with the question of the persistence of the Self. "Will there be nothing left of me, absolutely nothing?" (Chapman 2007: 33), a voice asks in a poem by Rabindranath Tagore.

But then, it is the intermedial context that largely contributes to the book's theme. The novel's references are predominantly clues to musical compositions, and they, too, point to death - Schubert's Die Winterreise, 
Mahler's "Der Abschied" from Das Lied von der Erde, or Schönberg's cantata, Gurrelieder, for instance. If the intersemiotic references are closely related to the novel's thematic background, it is above all thanks to their being vocal works - readable as texts and not scores, so that they create evocations not only owing to their musical potential, but also by a loop-like dynamics of intermediality, whereby the literary text comes into contact with the musical composition on the cusp of the very literariness of music, i.e. the text, the lyrics, the libretto. This brings to light a ricochet, a scalar system of intermediality, as if by a knock-on effect, by which a work's reference leads to yet another work or idea, at one with the multiplicity of a rhizome. For instance, the reference to the performance of Shostakovich's Viola Sonata (Chapman 2007: 56) is symbolic in itself, as his last work, while the mention of his Symphony $\mathrm{n}^{\circ} 14$ (Chapman 2007: 32) refers to a cycle of songs, all of which, in their turn, deal with death, mirroring the very effect of rhizome-like, loop-like, scalar intersemioticity on which Chapman's novel is founded. Hence, the intermedial reference to music is not fortuitous; the intersemiotic translation acquires meaning as a fully signifying element pertaining to a network of intersemiotic references revolving around a single theme that keeps multiplying and forking out.

One example of such complex ricochet intersemiotic structure resides in the mentioning of mythology and myth-inspired opera. The theme of death is exposed as a cultural discourse, handed down to us as with the myths of Orpheus or Echo. It seems unavoidable not to relate their cultural implications - the voice of the dead as spectre (Orpheus) or the fragmentary voice (Echo) - to a tradition of intersemioticity that has shaped Western musical culture, as in the two central references in the text: Monteverdi's

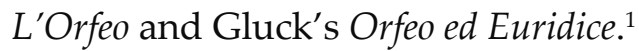

Consequently, the theme of death finds verification in questions of pain, time, memory, and the body. Intersemioticity brings us face to face with the logic of contiguity, of metonymy which reflects the necessary act of falling back on an ever-expanding otherness and absence. Intermediality seems as inconceivable as death itself and as puzzling as the very question of absent - yet to be sounded - voices. How is one to read a text that pretends to be a musical score? This is the paradoxical logic of the voice as a trace of (potential) performance and that of intersemioticity, both of which are tainted by this impossible, rhizome-like otherness of metonymy.

${ }^{1}$ Orpheus is one of the founding myths related to the voice that, according to Marie-France Castarède, has been perpetuated well into Western Christianity and its iconography (2004: 39). Interestingly, while the myth of Echo annihilates the fullness of the voice, with Orpheus the subject is atomized and scattered since the figure of Eurydice turns into a spectre that can be contemplated as stars in the sky. 


\section{The Intersemiotic Clash of Discourses}

Chapman's novel undoubtedly hints at the funeral homage, elements of which can be found - both in music and literature - in numerous poetic forms such as epicedium, threnody, requiem, lament, eulogy, tombeau, and so forth. The novel's ambiguity when it comes to its genre - novel, oratorio, and memoir - provides the essential foundation for questions relating to the generic nature of the text itself, with reference to funeral discourse as lamentation, commemoration, or tribute. Some excerpts recall genres, which revolve around memoirs and biographies, ${ }^{2}$ while other fragments clearly underline the primacy of funeral homage. ${ }^{3}$ The voice appears here through the multitude of origins and leads to a clash of discourses.

By and large, the generic instability is due to the novel's highly intertextual nature. If intertextuality may be said to be at its highest, here, it is because the text is almost exclusively made of references and quotations. Dozens of citations are presented on the page in a specific and highly organized way, creating the illusion that they function as a musical score. There is certainly room for references that are accompanied by short excerpts. But, notably, there is also a zero degree of citation, in which the reference remains sheer reference, so that the textual quote becomes no more than a bibliographical entry, as in the listing of sources at the end of the book. However, a reference appearing within the text differs from those to be found at the end of the book, insofar as it is granted vocal specificity by its very position within the score - the way in which it is supposed, however virtually, ${ }^{4}$ to be voiced and sounded. Hence, it is the (absent) voice - the trace of the voice - that is meant to give the text its intersemiotic status.

There is a form of coarseness or austerity to that isolated reference devoid of its context and the short citation isolated by the blank of the page. ${ }^{5}$ What shows through, is the gesture of cutting and pasting, that of the scissors,

\footnotetext{
2 Alma Mahler's Memories and Letters, Virginia Woolf's Diary, Glenn Gould's Notebook, Maurice Leonard's Kathleen, or Winifred Ferrier's The Life of Kathleen Ferrier.

${ }^{3}$ Bernstein's quotes dealing with Mahler, or the obituary of Gould hinting at the Requiem Mass: "At any rate, rest in peace Glenn Gould" (Chapman 2007: 45).

${ }^{4}$ The text intimates its very transcendence through possible executions. The score being reduced, condensed, the mere reference acts in the same way as the scoreless mention of instrumental parts, implying that there exists some form of exteriority bound to complete the text. This is part of the intersemiotic delusion - trompe-l'cil, as it were - with which the text toys.

${ }^{5}$ Antoine Compagnon insists that an isolated citation is devoid of meaning as such and needs its surrounding context (1979: 38).
} 
following Antoine Compagnon's words. ${ }^{6}$ The text seems to offer just a foretaste of the larger whole, like the $19^{\text {th }}$ century thematic catalogues of music, which provided the beginnings of compositions (Escal 1988: 100). Therefore, there is a mirage of continuation; the impression of a call for resumption. From this angle, the structural metaphor is that of the list or the catalogue, but also that of the compilation, the compendium, the anthology, and all forms of entry-texts that are inimical to exhaustiveness and founded on condensation and abbreviation. The text becomes a compiler's work, like in ancient chrestomathies and commonplace books (Miola 2004: 18), acting as a mirror of the $20^{\text {th }}$ century criticism of intertextuality itself, reminiscent of concepts such as Mikhail Bakhtin's heteroglossia or Roland Barthes' feuilleté $d u$ discours. It is as though the text's structure were the mirror of that very critique aiming to place it in exposure or to literalize it, as though to achieve a parodic distortion of heteroglossia itself.

But perhaps the best metaphorical template for Chapman's novel would be that of the extreme or absolute intertextuality represented by the cento. Originally, from Latin word cento, meaning a "quilt, blanket, or curtain made of old garments stitched together" (Okáčová 2009: 1), the term suggests a patchwork structure, a "collage of different voices". ${ }^{7}$ As a poetic mode, it is a peculiar genre, which highlights pure heteroglossia. When Marie Okáčová states that "the uniqueness of the cento consists in its absolute derivativeness" (2009:1), she shows that it is a wholly derived and derivative piece, like Chapman's novel.

The cento is illustrative of the multiplicity of voices and origins that, even though they are made to form one single piece, are irreducible one to the other and may well contradict each other, its elements appearing in contrasts and oppositions. The multifarious origins are, somewhat paradoxically, brought together without the possibility of coalescing: "[t]he cento variously pays homage to, parodies, and/or perverts its source text" (McCutcheon 2012: 79). This is equally the logic of the quodlibet in music. ${ }^{8}$ These structural templates lay the foundation for envisaging the voice

${ }^{6}$ Compagnon emphasizes the physical gesture of cutting and pasting as a fundamental literary experience (1979: 16). He asks whether the pleasure derived from reading is actually that of an interactive bricolage, a game, or a do-it-yourself activity (1979: 17).

7 Mark McCutcheon insists on this tradition of collage, remixes and mash-ups (2012: 79). The French Trésor de la Langue Française states the term dates back to the $4^{\text {th }}$ century and defines it as a composition made up of fragments ("pièce composée de vers ou de fragments de vers d'origines diverses").

${ }^{8}$ Defined as "a piece made up of different songs or fragments of songs thrown together often with the apparent aim of making an incongruous and absurd mixture of texts" (Grout and Palisca 1988: 253). 
here as a non autonomous construct, but a set of fragmentary presences related to absent sources, a network of vocal traces that contribute to the intersemiotic transmutation.

At the kernel of Chapman's mixture of voices lies hybridity. There are multiple forms of discourse, some being aphorisms, such as Emily Dickinson's "Those-dying then" (Chapman 2007: 40), others interviews or medical statements. Schönberg's celebration of death starkly contrasts with the lightness of dying in Hurt's "Let the Mermaids Flirt with Me", or with the crude and objective "Report on a mastectomy" (Chapman 2007: 17). "The Boys in the Back Room", sung by Marlene Dietrich, precedes a quote from Adolf Hitler's Mein Kampf. The pathetic and the lachrymose cohabit with the lighthearted. The Christian beliefs of transcendence and resurrection are sapped by nihilist opinions, like in the quote from Malraux's Lazarus which questions the "lunatic metempsychosis of the West" by reminding readers that " $[t]$ he dread of extinction is as meaningless as the dread of non birth" (Chapman 2007: 43). Some quotes are witty, others may leave one in bewilderment, as this elevation of cancer to a life principle: "Philosophy does not retain the notion that nature is self-destructive [...] we cannot hold the view that cancer has accidentally or purposely come into existence to destroy the body [...] Cancer is not a blunder, but one of the wonders in nature" (Chapman 2007: 19). Hence, the polyphonic nature of the text appears as a hybrid association of discourses.

But then, the text does not attempt to suggest a dialectic synthesis of opinions or any holistic assimilation of voices. It is does not lend itself to a synthesis of conflicting subjectivities. What is sought is a collision of voices. This is why the structural metaphor of the cento/quodlibet is operative as an extreme instance of - and thus, almost a caricature of - heteroglossia. Okáčová suggests that the cento embodies the Derridean paradox of deconstruction. ${ }^{9}$ The emphasis on the clash of discourses, through the form of the cento helps us get a better grasp of the nature of voice traces in Chapman, for it lays bare an intersemiotic agonistics. However, yet another formal metaphor is brought to bear on the novel - that of the funeral composition underlying Zimmerman's Requiem for a Young Poet.

9 This is all the more obvious, as the cento - traditionally understood as a frivolous, playful, minor genre - naturally undermines the themes of death and mourning. The cento, in other words, is at odds with the Requiem Mass. The text thus contains a harbinger of its own deconstruction within the very use of genre, which is not out of keeping with the polygeneric genesis of Zimmermann's work and the ludic, avowed polygenericity Chapman's composer avails himself of. 
Indeed, by building on the tradition of the funeral genre of the requiem, ${ }^{10}$ the two works come to be closely entwined. The requiem tradition casts a new light on the trace of the voice by suggesting that through lamentation the voice becomes a shriek and that it is partly an act, insofar as it stems from a vow, that of a peaceful rest. Nevertheless, Zimmermann's requiem does not entirely follow the traditional genre. Calling his requiem a lingual, Zimmermann toys with the notion of language and the tradition of commemoration. The figure of the poet, represented in the Requiem by the three writers who committed suicide - Vladimir Mayakovski, Sergei Esenin and Konrad Bayer to whom Chapman alludes - transforms the work into a universal tribute to any poet. ${ }^{11}$

In fact, the structure of Chapman's text is based on the programme established for the performance of Zimmerman's Requiem at Carnegie Hall on 20 April 1999. The programme presented an English translation as well as a graphic approximation of Zimmermann's Requiem, reliant on a form of condensation of the original work. ${ }^{12}$ Chapman's text follows suit and states: "[w]e have therefore introduced some simplifying features into the apparatus of this version" (Chapman 2007: 7). Hence, since the musical sign has been partly evacuated from the Carnegie Hall programme and from Chapman's novel, they both constitute an intersemiotic transmutation of the original score - an over-score of sorts. There only remains a trace of the initial intersemioticity, namely time indications related to musical time and the part-layout indicating voice entries (left and right margins of the page). Chapman does not borrow Zimmermann's divisions. The composer's Requiem is divided into Prologue, Requiem I, Requiem II (with five subsections) and Dona Nobis Pacem, while Chapman's is a two-part work. However,

${ }^{10}$ It should be remembered that a requiem is but a template - the text of the Mass for the Dead, upon which composers build their own music. The requiem, then, bears a specific intertextual and intersemiotic potential. The name derives from the first words of the Introit: requiem aeternam dona eis, Domine ("Grant them Eternal rest, O Lord"). A mass habitually comprises variable parts (Proper: Introit, Gradual, Alleluia, Offertory, Communion) and invariable parts (Ordinary: Kyrie, Gloria, Credo, Sanctus, Agnus Dei). In a requiem, Gloria or Credo are omitted, but the Tract and Dies Irae are added. For more details, see Grout (1988: 47-50), Michels (1988: 127), and Chase (2003: 2).

${ }^{11}$ It follows that the requiem lies in the context of the already long-standing tradition of tribute and non liturgical requiem, initiated in the $19^{\text {th }}$ century and pursued by many $20^{\text {th }}$ century composers. Chapman's text alludes not only to Mayakovski (Chapman 2007: 59) and Esenin (Chapman 2007: 58), but also to Zimmermann's own suicide (Chapman 2007: 59).

${ }_{12}$ The musical score was replaced by the text, so that its very intersemioticity was reduced. This gives the reader/audience the possibility of following the voices by identifying the sources and reading quotations in their entirety, whereas, in performance, they can appear as only partly audible conflicting fragments. 
Chapman does reproduce the essential elements from the part-distribution in Zimmermann, as is visible in the chart illustrating the analogy between the two works (Fig. 2).

Though partly eliminated, the voice remains on the page as a trace, inasmuch as its presence remains visible in the use of tracks, as in the original musical score. Both works make use of performing groups (choirs, soloists, speakers, instrumental parts and 4-track audio-tapes), so that the suggested intersemioticity resides in intermingling (a) live sung or spoken voices and (b) recorded sung or spoken voices..$^{13}$ Although Chapman does not resort to polyglotism, he follows in Zimmermann's footsteps by intimating that the original composition included passages in several languages. ${ }^{14}$ The soprano voice is replaced by a contralto. ${ }^{15}$ Both works make use of intertextuality by resorting to a high degree of sampling and collage, ${ }^{16}$ and their intertextual patterns offer telling comparisons (see Fig. 3 and 4).

While some of the sources are used in both works, the overall structure, as far as the distribution of sound sources and voices is concerned, displays similar patterns. A network of correspondences and connections is thus created.

If Chapman's novel brings to light multiple intermedial relationships, through its numerous references to music as well as its obvious link to Zimmermann's Requiem and the 1999 Carnegie Hall performance, it also reveals a polymorphic intertextual dimension, owing to the networks of references it draws on and its allusions to the sources in Zimmermann's composition.

${ }^{13}$ This mixture is reminiscent of earlier forms of spoken voice used in music, such as Schönberg's Sprechgesang and Sprechstimme.

${ }_{14}$ Zimmermann uses excerpts in Latin, German, Czech, English, Greek, Old Greek, Russian, Hungarian. Chapman's novel suggests that the initial score incorporated excerpts in German, Greek, Czech, Hungarian, Mandarin Chinese, French, Italian, Bengali, Sindhi, Hindi, Kannada, Sanskrit, Sumerian, Hebrew, Arabic, Russian, Portuguese, and English.

${ }_{15}$ Owing to the central role played by the English contralto Kathleen Ferrier.

16 While Zimmermann literally resorts to sampling, Chapman's text only evokes the technique. The very act of carving up the voice and reusing scraps seems to bridge the gap between the tradition of the cento and the contemporary remix culture. Both are subversive and deconstructing practices. McCutcheon states that the cento "constitutes a kind of meta-genre that simultaneously, paradoxically subverts the principle of genre [...] blurring the boundaries between primary and secondary cultural forms" (2012: 86). For Navas the remix culture "developed in a social context that demanded for a term that encapsulated the act of taking not from the world but an archive of representations of the world. In this sense, sampling can only be conceived culturally as a meta-activity [...]" (2012: 12). 


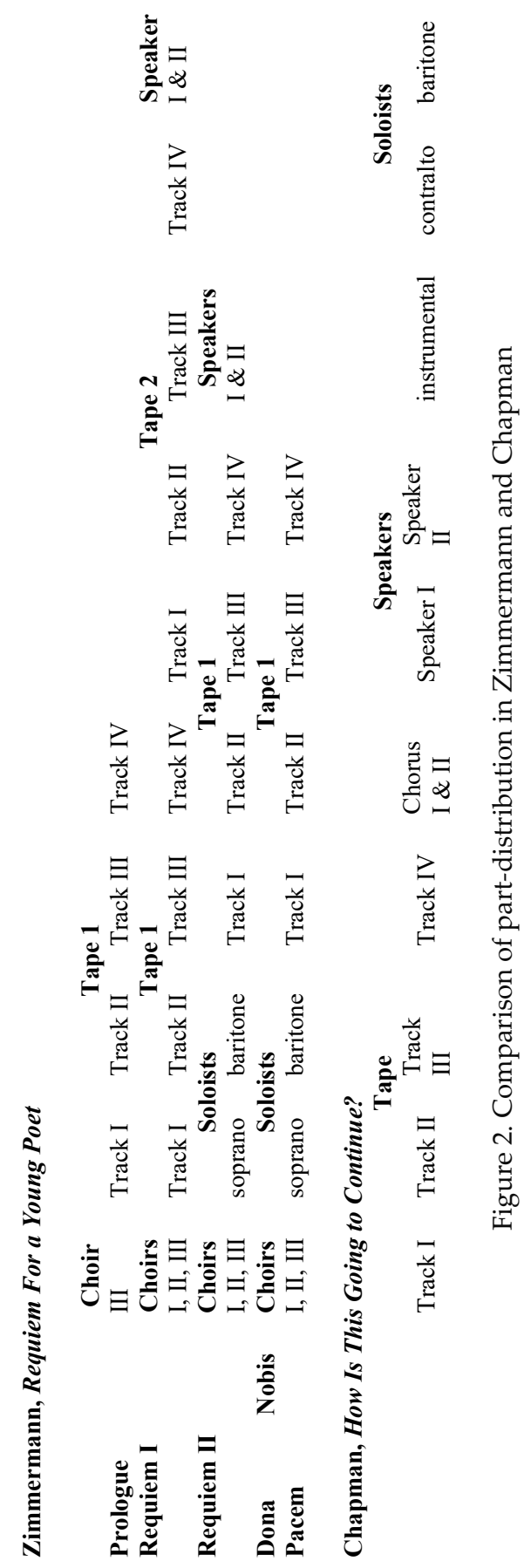




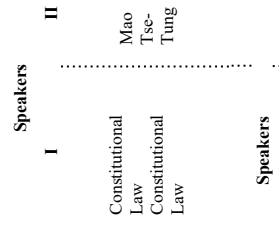

\section{I}
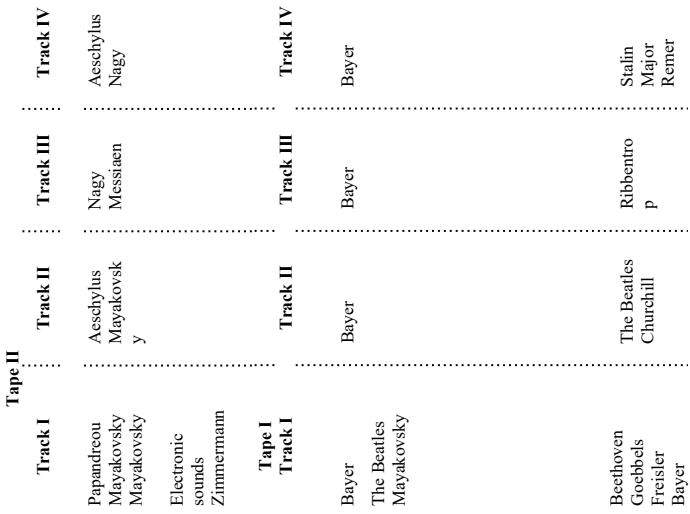

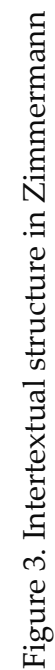

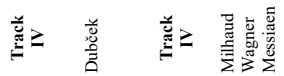

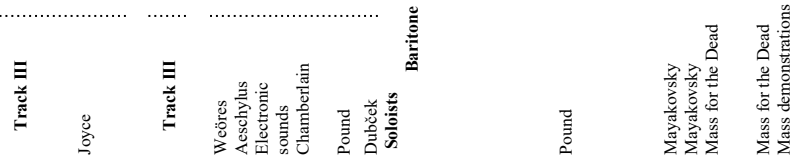

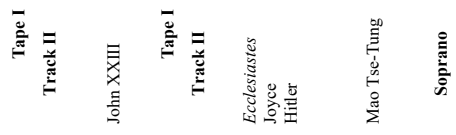

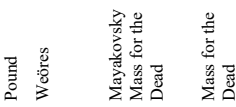

을

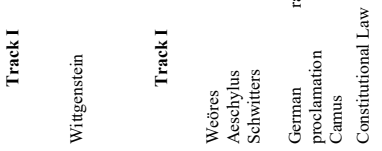

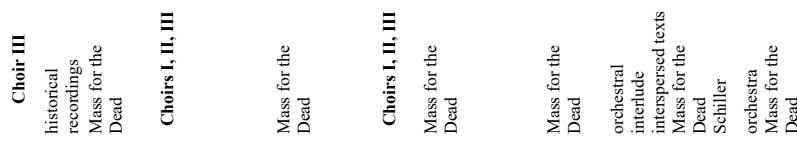

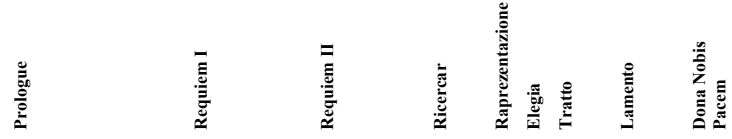




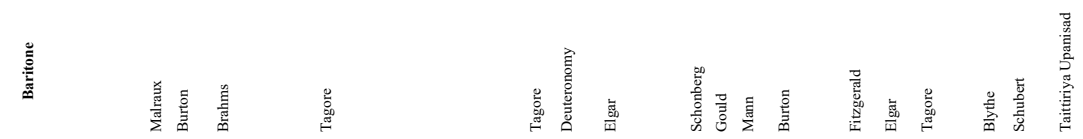

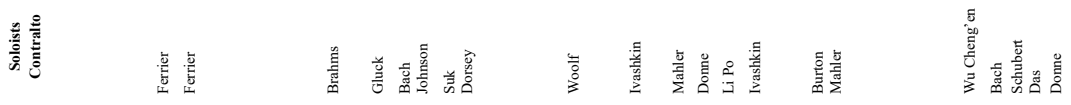

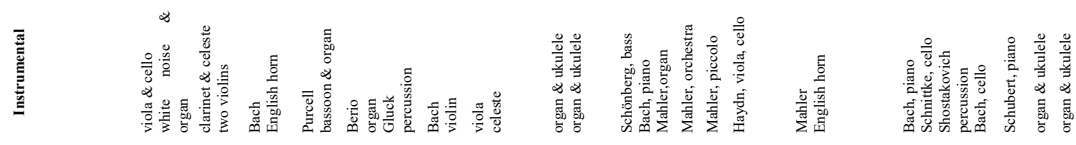

204

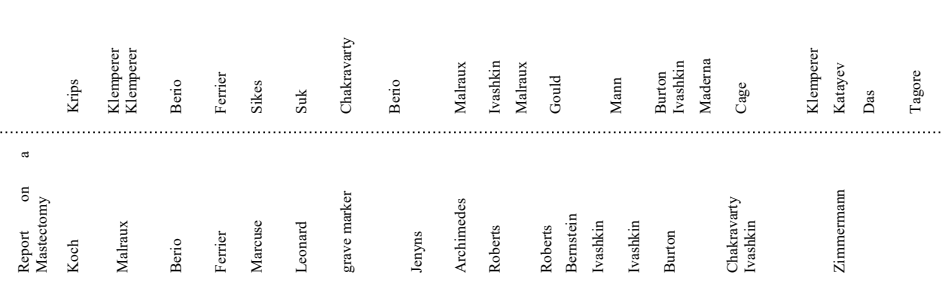

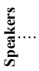

$$
\text { i }
$$

\#!

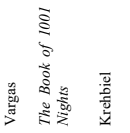

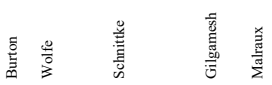

i

\section{Inllni | In:}

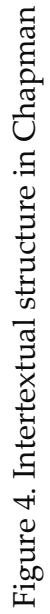

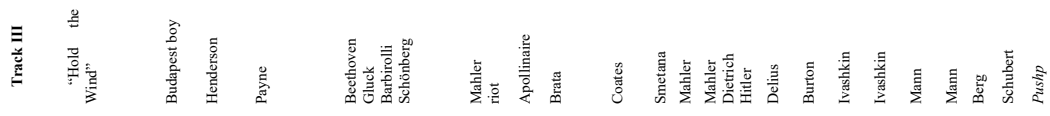

i

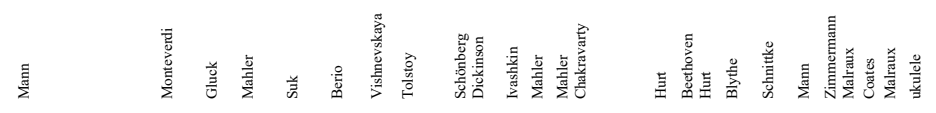

量咅

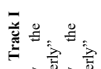

Whin an hally 


\section{Conclusion}

The analogies between Chapman's novel and Zimmermann's Requiem allow us to define intersemiotic translation here as a sophisticated network which: (a) constitutes a cento-like compilation of quotations, a collage of sources, excerpts, references and samplings; (b) is formed as a reply to a musical composition, thus an intermedial transmutation and sourceimitation; (c) evinces a multiple intertextual construct, based on a ricochetlike system of intertextual layers - a form of intertextuality of intertextuality; (d) displays a multiple intersemiotic construct, related to Zimmermann's and Chapman's references to musical compositions. Consequently, intersemioticity involves at once intertextual network-building and intermedial cross-reference. The work of the eccentric composer, Unruh, is made up of "musical quotes, speeches, songs, poetry, a trash-heap" (Chapman 2007: 11). The composer states that "all music can only be about previous music" (Chapman 2007: 52), so that it becomes "non-music" (Chapman 2007: 11). This idea of non-music characterizes the paradox of high intertextuality and intersemiotic translation here - Chapman's novel is music without ever being able to become a musical composition unless the reader recreates it from its palimpsest-like fragments. It is this trash-heap of intersemiotic references that confronts us with fragments of meaning and traces of absent voices. Since those voices are clues to performances, the references appear not merely as a list of compositions to be read, but they seem to constitute a call for an intersemiotic interactivity, so that it seems possible to reassemble the fragments, bringing this peculiar literary object to yet another level of transmutation in order to give it its due performance.

\section{References}

Bakhtin, Mikhail (1981). The Dialogic Imagination: Four Essays by M. M. Bakhtin. Austin: University of Texas Press.

Barthes, Roland (1984). "Le style et son image". In: Le Bruissement de La Langue. (141-150). Paris: Seuil.

Castarède, Marie-France (2004). La voix et ses sortilèges. Paris: Les Belles Lettres, Confluents Psychoanalytiques.

Chapman, James (2007). How Is This Going to Continue? New York: Fugue State Press. 
Chase, Robert (2003). Dies Irae: A Guide to Requiem Music. Lanham: Scarecrow Press.

Compagnon, Antoine (1979). La seconde main ou le travail de la citation. Paris: Seuil.

Escal, Françoise (1988). "Le thème en musique classique". Communications, Variations sur Le Thème 47: 93-117.

Grout, Donald Jay, Claude V. Palisca (1988). A History of Western Music. New York: W.W. Norton and Company.

Jakobson, Roman (1959). “On Linguistic Aspects of Translation". In: Selected Writings II. (260-66). The Hague: Mouton.

McCutcheon, Mark A. (2012). “The Cento, Romanticism, and Copyright”. English Studies in Canada 38 (2): 71-101.

Michels, Ulrich (1988). Guide illustré de la musique. Paris: Fayard.

Miola, Robert S. (2004). "Seven Types of Intertextuality". Shakespeare, Italy and Intertextuality. Ed. Michele Marrapodi. (13-25). Manchester: Manchester University Press.

Navas, Eduardo (2012). Remix Theory: The Aesthetics of Sampling. Wien: Springer.

Okáčová, Marie (2009). "Centiones: Recycled Art or the Embodiment of Absolute Intertextuality?" In: Kakanien revisited. (1-11). http://www.kakanien. ac.at/ beitr/graeca_latina/MOkacova1.pdf [accessed Jan. 18, 2014].

Trésor de la Langue Française. http://atilf.atilf.fr/ [accessed Jan. 18, 2014].

Zimmermann, Bernd Alois (1999). Requiem for a Young Poet. Carnegie Hall Programme, 20 April 1999. English trans. P. Sharpe. Mainz: Schott's Soehne. http://audiolabo.free.fr/revue1999/content/zimmermann1.htm [accessed Jan. 18, 2014]. 